\title{
Impact of Entrepreneurship Education on the development of Entrepreneurial Activities: The Case of Omani Undergraduate Students
}

\author{
Abdullah Mohammed Al Shukaili ${ }^{*}$, Norizan Mohd Kassim² ${ }^{2}$ Anju Ravi $^{3}$, Mohammed Muneerali ${ }^{4}$ \\ ${ }_{1,2,3,4}$ College of Economics, Management, and Information Systems \& Entrepreneurship Center University Nizwa.
}

\begin{abstract}
Supporting entrepreneurship and innovation has always been the important to the Sultanate of Oman's future. This research will shed light on the effectiveness of entrepreneurship education on the development of entrepreneurial activities in Oman. Large number of studies have concerned about entrepreneurship education, and entrepreneurial intention, but very few studies focusing on the how and why entrepreneurship education influences and their impact on entrepreneurial intention. Therefore, the objective of our study is to identify the impact of entrepreneurship education on entrepreneurship intention among undergraduate students in Oman. A survey questionnaire is used as the primary data collection tool by way of an online survey, and a sample from public and private Higher Education Institutions (HEIs) in Oman. The sample will consist of two groups selected among a population of undergraduate students who are in their final semester of study, and from those who have graduated during the previous two years. As this research is still in progress, we are expecting to collect a sample exceeding two hundred questionnaires. Preliminary testing of the model indicates that the survey instrument of this study is a fair, valid, and reliable method with which to conduct this field data collection. The research findings are expected to contribute to a greater understanding of the relationship between the various components of entrepreneurship education and the entrepreneurial intention of those undergraduate students from the target populations. Since increasing attention has been given to entrepreneurship and entrepreneurship education in Oman, in recent years, it is expected that the findings of this research will reveal the effectiveness of such programs in enhancing the potential of students to enable them to become effective, self-employed, entrepreneurs.
\end{abstract}

Keywords: Entrepreneurial Intention, Entrepreneurship Education, Theory of Planned Behavior, Education Components, Oman

\section{INTRODUCTION}

In recent years, innovation and entrepreneurship have been considered as the potential major drivers of economic growth in the Sultanate of Oman. Effective education in the field of entrepreneurship will develop entrepreneurs' knowledge and skills, and assist them to develop their ability to establish, and subsequently manage effectively, their business. Many empirical research studies have confirmed the importance of entrepreneurship education in creating new business ventures (Autio, Keeley, Klofsten, \& Ulfstedt, 1997; Bae, Tae Jun, Shanshan Qian, Chao Miao, \& James Fiet., 2014; Davidsson 1995; Tkachev \& Kolvereid, 1999, Chen et al., 1998; Lee et al., 2005). Despite the large number of studies dedicated to the analysis of entrepreneurship education and the entrepreneurial intention, very few have been conducted to determine how and why entrepreneurial education can influence the students' entrepreneurial intention (Fayolle, Gailly, \& Lassas-Clerc 2006; Sun, Hongyi, Choi Tung Lo, Bo Liang, \& Yuen Ling Belle Wong., 2017). Though research has also been carried out to define a generic description of the entrepreneurial attitude of Omani students (Al-Harthi, 2017; Al-Harrasi \& Al-Salti, 2014; Ibrahim, Devesh, \& Ubaidullah, 2017), the researchers were unable to source any that assessed and analyzed how specific education components affect students attitudes and intention. An effective entrepreneurship education program or course should result in the development of the essential entrepreneurial attributes.

\footnotetext{
*Corresponding Author: a.alshukaili@unizwa.edu.om
} 
Higher Education Institutions (HEIs) in Oman have integrated entrepreneurship as a mandatory subject in all their programs since the academic year of 2014/15. By doing so, they have assisted in cultivating an entrepreneurial mindset among the citizenship, through the students involved in higher education disseminating the perspective to the wider community. Supporting entrepreneurship and innovation has always been the important to the Sultanate of Oman's future. The main goal of this research is to contribute to the debate on the effectiveness of entrepreneurship education on the development of entrepreneurial activities. Therefore, the purpose of this study is to examine the impact of entrepreneurship education on the creation of entrepreneurship intention among undergraduate students in Oman. The research consulted previous works on the Theory of Planned Behavior (TPB) (Ajzen,1991; Krueger, 2009), the theory-grounded knowledge, proposed by Fayolle et al., (2006) and Fayolle \& Gailly, (2015) on entrepreneurship education (EE) theory (Nabi, Walmsley, Liñán, Akhtar, \& Neame, 2018), to design the conceptual framework of this study. The research also investigates the impact of entrepreneurship education (Know-what, know-how, know-who, and knowwhy) in entrepreneurial intention (attitudes, subjective norms and perceived behavior control), and the student's characteristics (gender, age, degree and if they studied the entrepreneurship course, or not), as a moderating variable.

Many previous research studies have confirmed the importance of entrepreneurship education in creating new business ventures, but few have investigated the effectiveness of entrepreneurship policy education, especially in developing countries. Therefore, this study provides a clear mapping model of entrepreneurial intention, based on the variety of attributes that characterize the significant representative sample. Additionally, it will assist the policymakers in developing and orientating various regional and national economic development programs to promote the entrepreneurship education. To facilitate that, a significant proportion of the intention are materialized in prime conditions, such as creating funding schemes, or developing infrastructure.

Hence, the objectives of the study are to investigate the formative process of entrepreneurial intention and to examine how specific education components influence Omani students' entrepreneurial attitudes and intention. In other words, the proposed study focuses on how the entrepreneurial intention of the students is formed through current academic entrepreneurial education programs.

\section{LiteratuRE REVIEW}

\section{The Emergence of Entrepreneurship Education}

All government sectors in a country have given their attention to encourage entrepreneurship education It is one of the government policies to promote entrepreneurial activities (O’Connor, Allan. 2013). Verheul, Ingrid, Sander Wennekers, David Audretsch, and Roy Thurik, (2001) stated that entrepreneurship education is focusing on the "promotion of entrepreneurship and stimulating entrepreneurial skills and knowledge" (p.34), which is different from general education. The debate in the literature is still not clear regarding the impact of entrepreneurship education in promoting entrepreneurial activities, as mixed findings from the literature have led to unclear conclusions (O’Connor, Allan. 2013).

The government of Oman has supported the growth of entrepreneurship activities within economic diversification, based on greater employment creation opportunities, innovation, and a forecast positive contribution to the Gross Domestic Product (GDP). The starting point of the government strategy to effectively support the start-ups and development of entrepreneurship was a request to the Higher Education Institutions (HEIs) in Oman to teach entrepreneurship to all undergraduate students. This decision-taking was based on the initial Sih Alshamkhat (Al Shanfari et al., 2013) decisions in January 2013 to support and enhance entrepreneurship in Oman and further assessment of the implementation of the Sih Alshamkhat decisions was made in 2015. One of the policy objectives developed from the symposium was related to entrepreneurship education. The objective was to increase the emphasis on entrepreneurship in the education system as follows (Al Shanfari et al., 2013):

- to provide a course in entrepreneurship for students in various institutions of higher education and support the implementation of student activities in cooperation with the private sector in the field of entrepreneurship, and

- to include entrepreneurship in school curricula and educational programs and use modern methods to instill an entrepreneurial mindset in young people.

Since then increasing attention has been given to entrepreneurship and entrepreneurship education in Oman. Many initiativesresearch, teacher training, curriculum development, pilot projects, and collaboration with international organizations- are undertaken to promote entrepreneurship. There are many support programs to promote entrepreneurship in the country. According to the official statistics of the Ministry of Higher Education, no less than 5,000 graduates are being produced by universities and 
colleges in Oman every year. A mandatory semester-long course on entrepreneurship has been introduced in all HEIs in the Sultanate of Oman for students entering higher education from Fall 2014/15 onwards.

\section{Entrepreneurship Education (EE) and Entrepreneurial Intention (EI)}

A growing body of work in entrepreneurship education (EE) literature has indicated interest in the effect of EE on student's entrepreneurship intentions (EI) at higher education institutions, and to investigate the significant impact of different component of an EE program in imparting EE at tertiary level (Bae et al., 2014; Blenker, Per, Poul Dreisler, Helle Meibom Faergemann, \& John Kjeldsen, 2008; Hussain \& Norashidah, 2015; Nowiński, Haddoud, Lančarič, Egerová, \& Czeglédi, 2019). Additionally, there are mixed findings from the literature regarding the relationship between EE and EI, for example, Halim, Malim, Hamdan, Salehan, \& Kamaruzzaman, (2019) and Nabi et al. (2018) found that EE inspires through developing students' EI in their first year in higher education, and the educational support being the most influential factor that affects EI levels of achievement. Similarly, the findings of Karimi, Biemans, Lans, Chizari, \& Mulder, (2016) reveal that the elective Entrepreneurship Education Programs (EEPs) have significantly increased students' EI, although this increase was insignificant for the compulsory EEPs. However, Hattab (2014) highlights the relationship between EE, intention, and perceived desirability, while no relationship existed with perceived feasibility or self-efficacy, and he further suggests that it is desirable to reform the educational system to boost creativity and innovativeness of students. Zhang, Duysters, and Cloodt (2014) studied the relationship between EE, prior entrepreneurial exposure, perceived desirability and feasibility, and EI for university students and found that there is a substantial positive interactive effect by university type, gender and study key, on the relationship between EE and EI.

On the other hand, Bilal, and Hussein (2019) in their research examined the influence of entrepreneurship and prior experience on student's job intention at Dhofar university in Oman and demonstrated that there is no relationship between student's career intention and EE, while there is a major relationship between previous experience and student's career intention in the university. Whereas Bakheet, Varghese, Al-Qartoopi, and Al-Hamdi (2019) found that there is an association between student's attitudes towards EI to start-up businesses.

\section{Theory of Planned Behaviour (TPB)}

Many empirical studies have used the Theory of Planned Behaviour ( TPB) to explain the relationship between the three attitudinal antecedents namely, attitude, subjective norms, and perceived behavior control, and their impact on EI ( Farrukh, Alzubi, Shahzad, Waheed, \& Kanwal, 2018; Lortie \& Castogiovanni, 2015; Sun et al., 2017). Arán, Sanchez, and Molina, (2015) suggested that perceived behavioral control and attitudes affect the EI of university students towards entrepreneurship. In emerging countries like India, Kumar and Das (2019) reported that there is a positive association between peer effect and an individual attitude towards entrepreneurship, while in an entrepreneurial ecosystem, the institutional infrastructure moderates the relationship between attitude and EI but not entrepreneurial self-efficacy. In addition, they also found that gender plays a significant role in choosing entrepreneurship as a career in India.

Interestingly, according to Schölin, Broomé, and Ohlsson (2016), the influence that family factors have on an individual's choice of business is strong. That is, individuals whose parents have business ventures are very much more likely to continue with their parent's business. Using an extended model of Ajzen's TPB model, Fernández, Montes, Rodríguez, and Alonso (2017) suggest that emotional competencies play an extremely important role in shaping students' entrepreneurial intention, and have a positive impact on their entrepreneurial attitudes and perceived self-efficacy. Moreover, they observed that a higher degree of emotional competency in entrepreneurship education, the more positive attitude shown by students towards entrepreneurship, and they will perceive themselves as more talented and more ready to become entrepreneurs. Another study by Yousaf, Shamim, Siddiqui, \& Raina, (2015) highlighted that students' perceived desirability, entrepreneurial attitude, and subjective norms, significantly lead to the improvement of students' intentions to become entrepreneurs. Miranda González et al., (2017) conducted a study on 1178 Spanish university academics and the results from the structural equation model indicated that entrepreneurial intention is influenced by the attitude towards entrepreneurship, which in turn was influenced by creativity, perceived utility, and entrepreneurial experience. Thus, the mixed findings derived from the above studies together suggest that there are gaps, or omissions, within the literature. 


\section{Entrepreneurship Education Components}

Indeed, entrepreneurial knowledge and skills gained through entrepreneurship education will be expected to create and boost the entrepreneurial intention (Bhat \& Singh, 2018; Cho,1998; Karimi et al., 2016, Islamic 2018). It is evident in the literature that entrepreneurship education is an effective way to increase the venturing rate of engineering graduates (Menzies \& Paradi, 2002), and students' entrepreneurial attitudes (Al Bakri \& Mehrez, 2017). Linan (2004) proposed that there were four levels of entrepreneurship education, namely entrepreneurial awareness education, education for start-up, education for entrepreneurial dynamism and continuing education for entrepreneurs. Similarly, to Johannisson (1991) where he suggested that there is a classification scheme defining specific categories for entrepreneurial learning, that is, know-what (entrepreneurial knowledge), know-why (values and motives), know-who (social interaction) and know-how (entrepreneurial skills and abilities). Know-what refers to the concept and knowledge of entrepreneurship, know-why is about the values and motives of initiating entrepreneurial events and attitudes toward the events, know-who concerns the social interaction shown through the interaction with teachers, successful entrepreneurs, and experts in the research field. Finally, know-how represents abilities, techniques, and skills.

Based on Ajzen's TPB theory that the stronger the intention to accomplish behavior, the more expectation there is the behavior will be accomplished. According to Sun et. al. (2017) that the four of EE components (Why, What, How, and Who) were found to be interrelated with, and influenced, the three TPB antecedent variables (attitude, social norm, self-efficacy), and EI where the know-what component was treated as the independent variable in their proposed conceptual framework. Additionally, they reported that subjective norm plays a significant role in facilitating attitudes towards entrepreneurship, as well as self-efficacy or perceived behavioral control (PCB), while PBC was also seen to improve one's attitude towards entrepreneurship. Their model suggests a systematic impact of EE on EI.

Following this rationale, and the review of the literature, Figure (1) presents the proposed conceptual framework for this study which is based on Sun et al. (2017). The list of hypotheses which are extracting from this framework are summarized in Table (1).

\section{PROPOSED THEORETICAL FRAMEWORK AND HYPOTHESIS}

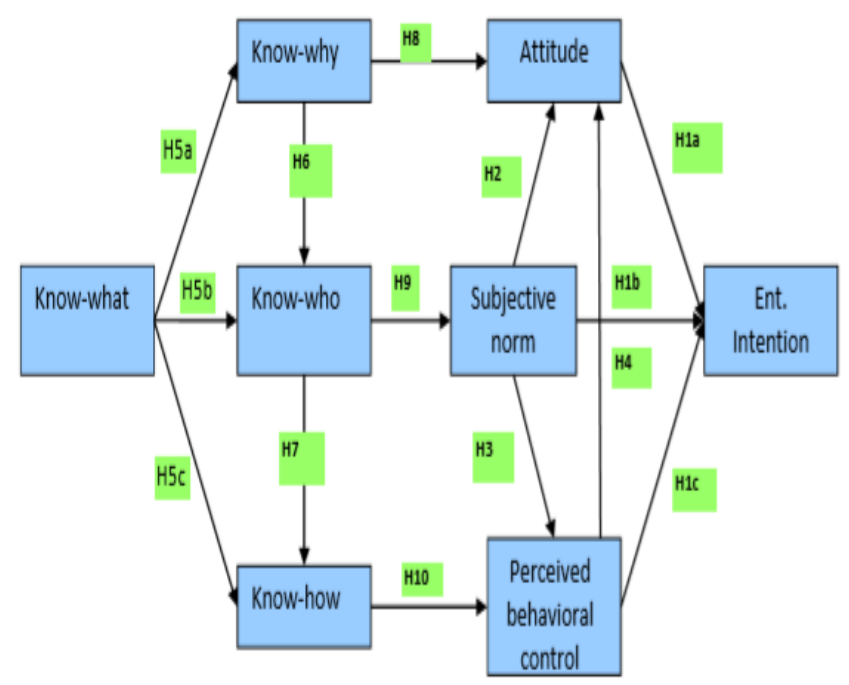

Figure (1): Proposed Conceptual Framework and Hypotheses

Source: Adapted from Sun et al. (2017) 
Table (1): List of proposed hypotheses

\begin{tabular}{|c|c|}
\hline Hypothesis & Description \\
\hline $\mathrm{H}_{\mathrm{la}, \mathrm{b}, \text { and } \mathrm{c}}$ & $\begin{array}{l}\text { There is a positive relationship between the three TPB antecedent variables of (a) attitude, (b) } \\
\text { subjective norm and (c) PBC on the entrepreneurial intention of Omani students. }\end{array}$ \\
\hline $\mathrm{H}_{2}$ & $\begin{array}{c}\text { There is a positive relationship between subjective norms and the students' attitudes toward } \\
\text { entrepreneurship. }\end{array}$ \\
\hline $\mathrm{H}_{3}$ & $\begin{array}{c}\text { Subjective norms affect the perceived behavioural tendencies of students to engage in } \\
\text { entrepreneurial activities. }\end{array}$ \\
\hline $\mathrm{H}_{4}$ & Perceived behavioural control affects the attitudes of students toward entrepreneurship. \\
\hline $\mathrm{H}_{5}$, a b, and c & $\begin{array}{l}\text { Know-what of the EE component influences EE components of (a) know-why, (b) know-who } \\
\text { and (c) know-how. }\end{array}$ \\
\hline $\mathrm{H}_{6}$ & Know-why of the EE component influences EE component of know-who. \\
\hline $\mathrm{H}_{7}$ & Know-who of the EE compone \\
\hline $\mathrm{H}_{8}$ & Know-why of the EE component influences attitude toward entrepreneurship. \\
\hline $\mathrm{H}_{9}$ & Know-who of the EE component influences subjective norms. \\
\hline $\mathrm{H}_{10}$ & The EE component know-how influences perceived behavioural control. \\
\hline
\end{tabular}

\section{SIGNIFICANCE OF THE STUDY}

Gaps in the literature. There is a current lack of consensus in the literature, regarding the impact of entrepreneurship education, in promoting entrepreneurial activities. Few studies have been conducted to study how and why entrepreneurial education influence and impact entrepreneurial intention (Fayolle et al., 2006; Sun et al., 2017).

Size and changes in the industry. The mandatory semester-long course on entrepreneurship has been introduced in all Higher Education Institutions (HEIs) in the Sultanate of Oman for the students entering higher education since Fall 2014/15. In this context, this research intends to study the formation process of entrepreneurial intention and to identify which specific education components, influence Omani students' entrepreneurial attitudes and intention. The study will focus on how the entrepreneurial intention of the students is formed through entrepreneurial education.

Potential benefits. This study will add to the existing body of literature in assessing the effectiveness of various learning components on creating an entrepreneurial intention. The study results will shed light on the impact of compulsory entrepreneurial education in developing entrepreneurial intention among Omani graduating students. The effectiveness of the compulsory entrepreneurship course can be gauged from the results of the study. Based on the same policymakers can formulate new policies to foster entrepreneurship inside the country. The study may also provide insights to Higher Educational Institutions to redesign their entrepreneurship curriculum.

In sum, this research is justified on the above three conceptual and practical perspectives.

\section{METHODOLOGY}

A hypothesis testing approach will be used because one of the objectives of this study is to generalize the findings of the population. The stratified sampling method will be used that consists of two groups selected among the targeted population for undergraduate students who is in the last semester, and from those students who have already graduated in the last two years. Since this research is still in progress, we are expected to collect a sample between 200-300. The variables used in this research are adapted from Sun et. al. (2017) and summarized in table 2. 
Table 2. List of variables used in the study

\begin{tabular}{ll}
\hline Variable & Description \\
\hline Know-what & $\begin{array}{l}\text { This is the independent variable which describes the entrepreneurial knowledge and } \\
\text { concepts required by students to understand before starting a business, for instance know } \\
\text { to find business opportunity, generate idea, understanding government support } \\
\text { programs and so on. } \\
\text { This is a mediation variable which defines the motivations received by students to } \\
\text { engage in entrepreneurial activities like taking the entrepreneurship course, and teaching } \\
\text { methods } \\
\text { Know-why }\end{array}$ \\
$\begin{array}{l}\text { This is a mediation variable which refers to social interaction required by students to } \\
\text { obtain information and resources needed to start business, like developing networks, } \\
\text { professors at HEIs, guest speakers, and knowing successful entrepreneurs' stories }\end{array}$ \\
This is a mediation variable which refers to skills and abilities to start business like \\
understanding how to develop business plan, and the enhancement of entrepreneurship \\
course in this regard \\
This is a mediation variable which indicates the beliefs and feeling to preform future \\
entrepreneurial activities by students who are graduated or going to graduate from Oman
\end{tabular}

Source: adapted from Sun et. al. (2017)

A survey questionnaire design based on the above variables was developed and measured using the 5-point Likert scale measured from 1 'strongly disagree,' to 5 'strongly agree.' A preliminary survey was conducted to test the reliability and validity of the instrument. The research also utilized Cronbach to test the reliability with the objective of confirming the suitability of the research instrument (standard research questionnaire) after utilizing tested scales in existing literature. The correlation analysis also used Pearson Correlation to test the validity, as these are common technical properties used at this stage (Pallant, Haines, Green, Toohill, Gamble, Creedy, \& Fenwick, 2016). However, we intend to conduct an in-depth analysis using confirmatory factor analysis (CFA) after we collected enough data through the actual field work of the study. Harman's single factor test will be used to test the common method bias. The control variable in this study will be those students who have not yet registered in, studied, or completed the entrepreneurship courses.

Two types of data analyses will be used, being descriptive and inferential statistics. Descriptive statistics are used to describe the basic features of the data in the study, for example, simple summaries about the sample and the measures, while inferential statistics are used to test the hypotheses using structural equation modeling (SEM) statistical technique.

\section{FINDINGS AND DISCUSSION}

The results of the reliability and validity tests are shown in table 3 . The sample size in the pilot study consisted of 31 students. The Cronbach alpha of all the variables is excellent. However, as for the validity test, multi-co-linearity exists within almost all the variables. One possible explanation for such existence could be of the small sample size. Moreover, since the questionnaire is adapted and validated from the previous study, content (or face) validity is appropriate and sufficient for the validity test (Pallant et al., 2016). We requested two professors in senior institutional management, versed in research, for their feedback on the questionnaire prior to conducting the pilot test to confirm the selection of scale items based on the past empirical study and theoretical consideration. In brief, we can confirm that the instrument was found to be reliable and valid. 
Table 3. Pilot test results of reliability and validity tests

\begin{tabular}{lcccccccc}
\hline \multicolumn{1}{c}{ Item } & Atti & Sub_norm & PBC & EI & $\begin{array}{c}\text { Know- } \\
\text { what }\end{array}$ & $\begin{array}{c}\text { Know- } \\
\text { why }\end{array}$ & $\begin{array}{c}\text { Know- } \\
\text { who }\end{array}$ & $\begin{array}{c}\text { Know- } \\
\text { how }\end{array}$ \\
\hline Atti & 1 & & & & & & & \\
Sub_norm & $.808^{* *}$ & 1 & & & & & & \\
PBC & $.508^{* *}$ & $.662^{* *}$ & 1 & & & & & \\
EI & $.508^{* *}$ & $.711^{* *}$ & $.807^{* *}$ & 1 & & & & \\
Know-what & $.784^{* *}$ & $.926^{* *}$ & $.757^{* *}$ & $.797^{* *}$ & 1 & & & \\
Know-why & $.758^{* *}$ & $.842^{* *}$ & $.532^{* *}$ & $.685^{* *}$ & $.797^{* *}$ & 1 & & \\
Know-who & $.740^{* *}$ & $.813^{* *}$ & $.683^{* *}$ & $.762^{* *}$ & $.831^{* *}$ & $.870^{* *}$ & 1 & \\
Know-how & $.694^{* *}$ & $.808^{* *}$ & $.698^{* *}$ & $.757^{* *}$ & $.822^{* *}$ & $.930^{* *}$ & $.874^{* *}$ & 1 \\
Mean & 4.282 & 4.733 & 4.200 & 4.123 & 4.800 & 4.827 & 4.627 & 4.812 \\
Std. Dev. & 1.605 & 1.633 & 1.398 & 1.464 & 1.561 & 1.562 & 1.539 & 1.627 \\
Cronbach's Alpha & 0.899 & 0.939 & 0.915 & 0.915 & 0.964 & 0.96 & 0.938 & 0.957 \\
\hline *** significant at 0.01 level (two-tailed) & & & & & & &
\end{tabular}

\section{Conclusion}

The purpose of this research is to contribute to the debate on the impact of entrepreneurship education on the development of entrepreneurial activities specifically in developing countries. After conducting the preliminary test (reliability and validity), we can conclude that the model is acceptable to proceed to the next stage of collecting data.

Supporting entrepreneurship and innovation are important to the Sultanate of Oman's future. This study contributes to the literature in assessing the effectiveness of various learning components on entrepreneurial intention. This research project is a pioneering, large-scale empirical study, that intends to produce statistical evidence as to whether the entrepreneurship education program is effectively and efficiently conducted and is resulting in the development of the entrepreneurial attributes of Omani graduating students, or not. The results of the study will shed light on the policies and strategies that should be undertaken by all stakeholders to invigorate self-employment, and entrepreneurial sector employment, in the country. In addition, the findings of the study may identify gaps in either the teaching programs, content, or methodologies utilized in the entrepreneurship education courses offered in higher education institutions throughout the Sultanate of Oman, and if so, will seek to offer viable solutions. Finally, the research seeks to offer recommendations to policymakers and HEIs to enhance the prospect of achievement of the national objectives of entrepreneurially focused education, increased sector employment, and increased contributions to the national GDP.

\section{REFERENCES}

1. Abadie, Alberto, and Guido Imbens. 2002. Simple and Bias-Corrected Matching Estimators [ Technical Report]. National Bureau of Economic Research Cambridge, Mass., USA. http://www.nber.org/papers/t0283 (November 17, 2015).

2. Abadie, Alberto, and Guido W. Imbens. 2012. "Bias-Corrected Matching Estimators for Average Treatment Effects." Journal of Business \& Economic Statistics. http://amstat.tandfonline.com/doi/abs/10.1198/jbes.2009.07333 (March 26, 2016).

3. Ajzen, Icek. 1991. "The Theory of Planned Behavior." Organizational Behavior and Human Decision Processes 50(2): 179-211.

4. Ajzen, I. (2015). The theory of planned behaviour is alive and well, and not ready to retire: a commentary on Sniehotta, Presseau, and Araújo-Soares. Health psychology review, 9(2), 131-137.

5. Al Bakri, A., \& Mehrez, A. (2017). Factors influencing entrepreneurial intentions among Arab students. International Journal of Entrepreneurship.

6. Al-Harrasi, A. S., \& Al-Salti, Z. S. (2014). Entrepreneurial intention among information systems (IS) students at sultan qaboos university: an exploratory study. Global Journal of Management And Business Research.

7. Al-Harthi, A. S. A. (2017). Understanding entrepreneurship through the experiences of Omani entrepreneurs: implications for entrepreneurship education. Journal of Developmental Entrepreneurship, 22(01), 1750001. 
8. Al-Shanfari, D., Al-Said, A., Al-Said, F., \& Al-Busaidi, S. (2013). SME Development Symposium, the Main Report. unpublished, Muscat, Oman: Sultan Qaboos University.

9. Autio, E., Keeley, R. H., Klofsten, M., \& Ulfstedt, T. (1997). Entrepreneurial intention among students: testing an intention model in Asia, Scandinavia and USA.

10. Awang, A., Amran, S., Nor, M. N. M., Ibrahim, I. I., \& Razali, M. F. M. (2016). Individual entrepreneurial orientation impact on entrepreneurial intention: Intervening effect of PBC and subjective norm. Journal of Entrepreneurship, Business and Economics, 4(2), 94-129.

11. Bae, Tae Jun, Shanshan Qian, Chao Miao, and James O. Fiet. 2014. "The Relationship Between Entrepreneurship Education and Entrepreneurial Intentions: A Meta-Analytic Review." Entrepreneurship Theory and Practice 38(2): 21754.

12. Blenker, Per, Poul Dreisler, Helle Meibom Faergemann, and John Kjeldsen. 2008. "A Framework for Developing Entrepreneurship Education in a University Context.” International Journal of Entrepreneurship and Small Business 5(1): 45-63.

13. Bakheet, A. H., Varghese, T., Al-Qartoopi, K., \& Al-Hamdi, F. (2019). University Students' Entrepreneurial Attitudes and Intention: The Omani Context.

14. Babu, C., \& Kasilingam, R. (2015). Entrepreneurial Capability of Micro Entrepreneurs. BVIMR Management Edge, 8(1).

15. Bilal, Z. O., \& Hussien, M. A. (2019). The Impact Of Entrepreneurship Education And Previous Experience On students' career Intentions In Oman? Evidence from Dhofar University.

16. Cera, E., \& Furxhiu, N. (2017). Factors which Influence Students Enterpreneurship Intentions: The Role of Education Programs, Subjective Norms and Perceived Behavioral Control. Journal of Educational and Social Research, 7(1), 173179.

17. Chen, C. C., Greene, P. G., \& Crick, A. (1998). Does entrepreneurial self-efficacy distinguish entrepreneurs from managers?. Journal of business venturing, 13(4), 295-316.

18. Davidsson, P. (1995). Culture, structure and regional levels of entrepreneurship. Entrepreneurship \& Regional Development, 7(1), 41-62.

19. Espiritu-Olmos, R., \& Sastre-Castillo, M. A. (2015). Personality traits versus work values: Comparing psychological theories on entrepreneurial intention. Journal of Business Research, 68(7), 1595-1598.

20. Farrukh, M., Alzubi, Y., Shahzad, I. A., Waheed, A., \& Kanwal, N. (2018). Entrepreneurial intentions: the role of personality traits in perspective of theory of planned behaviour. Asia Pacific Journal of Innovation and Entrepreneurship, 12(3), 399-414.

21. Fayolle, Alain, Benoît Gailly, and Narjisse Lassas-Clerc. 2006. "Assessing the Impact of Entrepreneurship Education Programmes: A New Methodology.” Journal of European Industrial Training 30(9): 701-20.

22. Fayolle, A., \& Gailly, B. (2015). The impact of entrepreneurship education on entrepreneurial attitudes and intention: Hysteresis and persistence. Journal of small business management, 53(1), 75-93.

23. Fernández Pérez, V., Montes Merino, A., Rodríguez Ariza, L., \& Alonso Galicia, P. E. (2017). Emotional competencies and cognitive antecedents in shaping students entrepreneurial intention: the moderating role of entrepreneurship education. International Entrepreneurship and Management Journal. First online: 24 February 2017. Doi: 10.1007/s11365-017-04387. Management.

24. Fuller, B., Liu, Y., Bajaba, S., Marler, L. E., \& Pratt, J. (2018). Examining how the personality, self-efficacy, and anticipatory cognitions of potential entrepreneurs shape their entrepreneurial intentions. Personality and Individual Differences, 125, 120-125.

25. Gorgievski, M. J., Stephan, U., Laguna, M., \& Moriano, J. A. (2018). Predicting entrepreneurial career intentions: values and the theory of planned behavior. Journal of career assessment, 26(3), 457-475.

26. Halim, F. A., Malim, M. R., Hamdan, S. I., Salehan, A., \& Kamaruzzaman, F. S. (2019). Factors Affecting Entrepreneurial Intention Among IKN Students. In Proceedings of the Third International Conference on Computing, Mathematics and Statistics (iCMS2017) (pp. 545-554). Springer, Singapore.

27. Hattab, H. W. (2014). Impact of entrepreneurship education on entrepreneurial intentions of university students in Egypt. The Journal of Entrepreneurship, 23(1), 1-18.

28. Hussain, A., \& Norashidah, D. (2015). Impact of entrepreneurial education on entrepreneurial intentions of

29. Ibrahim, O. A., Devesh, S., \& Ubaidullah, V. (2017). Implication of attitude of graduate students in Oman towards entrepreneurship: an empirical study. Journal of Global Entrepreneurship Research, 7(1), 8. 
30. Johannisson, B. (1991). University training for entrepreneurship: Swedish approaches. Entrepreneurship \& Regional Development, 3(1), 67-82

31. Pakistani Students. Journal of Entrepreneurship and Business Innovation, 2(1), 43-53.

32. Joseph, I. (2017). Factors influencing international student entrepreneurial intention in Malaysia. American Journal of Industrial and Business Management, 7(04), 424.

33. Karimi, S., Biemans, H. J., Lans, T., Chizari, M., \& Mulder, M. (2016). The impact of entrepreneurship education: A study of Iranian students' entrepreneurial intentions and opportunity identification. Journal of Small Business Management, 54(1), 187-209.

34. Kumar, S., \& Das, S. (2019). An extended model of theory of planned behaviour: Entrepreneurial intention, regional institutional infrastructure and perceived gender discrimination in India. Journal of Entrepreneurship in Emerging Economies.

35. Krueger, Norris F. 2009. "The Micro-Foundations of Entrepreneurial Learning And... Education: The Experiential Essence of Entrepreneurial Cognition." Handbook of university-wide entrepreneurship education: 35-59.

36. Law, K. M., \& Breznik, K. (2017). Impacts of innovativeness and attitude on entrepreneurial intention: Among engineering and non-engineering students. International Journal of Technology and Design Education, 27(4), 683-700.

37. Lee, S. M., Chang, D., \& Lim, S. B. (2005). Impact of entrepreneurship education: A comparative study of the US and Korea. The international entrepreneurship and management journal, 1(1), 27-43.

38. Liñán, F. (2004). Intention-based models of entrepreneurship education. Piccolla Impresa/Small Business, 3(1), 11-35.

39. Lortie, J., \& Castogiovanni, G. (2015). The theory of planned behavior in entrepreneurship research: what we know and future directions. International Entrepreneurship and Management Journal, 11(4), 935-957.

40. Maresch, D., Harms, R., Kailer, N., \& Wimmer-Wurm, B. (2016). The impact of entrepreneurship education on the entrepreneurial intention of students in science and engineering versus business studies university programs. Technological forecasting and social change, 104, 172-179.

41. Menzies, T., \& Paradi, J. C. (2002). Encouraging technology-based ventures: Entrepreneurship education and engineering graduates. New England Journal of Entrepreneurship, 5(2), 9.

42. Miranda, F. J., Chamorro-Mera, A., \& Rubio, S. (2017). Academic entrepreneurship in Spanish universities: An analysis of the determinants of entrepreneurial intention. European research on management and business economics, 23(2), 113122.

43. Nabi, G., Walmsley, A., Liñán, F., Akhtar, I., \& Neame, C. (2018). Does entrepreneurship education in the first year of higher education develop entrepreneurial intentions? The role of learning and inspiration. Studies in Higher Education, 43(3), 452-467.

44. Nowiński, W., Haddoud, M. Y., Lančarič, D., Egerová, D., \& Czeglédi, C. (2019). The impact of entrepreneurship education, entrepreneurial self-efficacy and gender on entrepreneurial intentions of university students in the Visegrad countries. Studies in Higher Education, 44(2), 361-379.

45. O’Connor, Allan. 2013. “A Conceptual Framework for Entrepreneurship Education Policy: Meeting Government and Economic Purposes.” Journal of Business Venturing 28(4): 546-63.

46. Pablo-Lerchundi, I., Morales-Alonso, G., \& González-Tirados, R. M. (2015). Influences of parental occupation on occupational choices and professional values. Journal of Business Research, 68(7), 1645-1649.

47. Pallant, J. F., Haines, H. M., Green, P., Toohill, J., Gamble, J., Creedy, D. K., \& Fenwick, J. (2016). Assessment of the dimensionality of the Wijma delivery expectancy/experience questionnaire using factor analysis and Rasch analysis. $B M C$ pregnancy and childbirth, 16(1), 361 .

48. Piperopoulos, P., \& Dimov, D. (2015). Burst bubbles or build steam? Entrepreneurship education, entrepreneurial selfefficacy, and entrepreneurial intentions. Journal of Small Business Management, 53(4), 970-985.

49. Rehan, F., Block, J. H., \& Fisch, C. (2019). Entrepreneurship in Islamic communities: How do Islamic values and Islamic practices influence entrepreneurship intentions?. Journal of Enterprising Communities: People and Places in the Global Economy, Forthcoming.

50. Robledo, J. L. R., Arán, M. V., Sanchez, V. M., \& Molina, M. Á. R. (2015). The moderating role of gender on entrepreneurial intentions: A TPB perspective. Intangible Capital, 11(1), 92-117.

51. Schölin, T., Broomé, P., \& Ohlsson, H. (2016). Self-employment: the significance of families for professional intentions and choice of company type. International Journal of Entrepreneurial Behavior \& Research, 22(3), 329-345.

52. Solesvik, M., Westhead, P., \& Matlay, H. (2014). Cultural factors and entrepreneurial intention: The role of entrepreneurship education. Education+ Training, 56(8/9), 680-696. 
53. Sun, Hongyi, Choi Tung Lo, Bo Liang, and Yuen Ling Belle Wong. 2017. "The Impact of Entrepreneurial Education on Entrepreneurial Intention of Engineering Students in Hong Kong.” Management Decision.

54. Tkachev, A., \& Kolvereid, L. (1999). Self-employment intentions among Russian students. Entrepreneurship \& Regional Development, 11(3), 269-280.

55. Tung, L. C. (2011). The impact of entrepreneurship education on entrepreneurial intention of engineering students. City University of Hongkong: Run Run Shaw Library.

56. Usaci, D. (2015). Predictors of professional entrepreneurial intention and behavior in the educational field. Procedia-Social and Behavioral Sciences, 187, 178-183.

57. Utami, C. W. (2017). Attitude, Subjective Norm, Perceived Behaviour, Entrepreneurship Education and Self Efficacy Toward Entrepreneurial Intention University Student In Indonesia.

58. Verheul, Ingrid, Sander Wennekers, David Audretsch, and Roy Thurik. 2001. An Eclectic Theory of Entrepreneurship: Policies, Institutions and Culture. Tinbergen Institute. Tinbergen Institute Discussion Paper. http://ideas.repec.org/p/dgr/uvatin/20010030.html (November 21, 2013).

59. Yousaf, U., Shamim, A., Siddiqui, H., \& Raina, M. (2015). Studying the influence of entrepreneurial attributes, subjective norms and perceived desirability on entrepreneurial intentions. Journal of Entrepreneurship in Emerging Economies, 7(1), 23-34.

60. Zhang, Y., Duysters, G., \& Cloodt, M. (2014). The role of entrepreneurship education as a predictor of university students' entrepreneurial intention. International entrepreneurship and management journal, 10(3), 623-641. 